\title{
QUALITY OF HEALTH SERVICE OUTPATIENT UNIT UPT PUSKESMAS CIPUTAT TIMUR, 2019
}

\author{
${ }^{1}$ Della Dwi Ayu, ${ }^{2}$ Fajar Ariyanti \\ ${ }^{1,2}$ Public Health Study Program, Faculty of Health Sciences, Syarif Hidayatullah State Islamic University \\ Jakarta \\ Pisangan, Jl. Kertamukti No.5, Cireundeu, Kec. East Ciputat, South Tangerang City, Banten 15419 \\ E-mail: delladwiayu23@gmail.com
}

\begin{abstract}
One of the SDGs targets in achieving UHC is increasing access to quality essential health services. Puskesmas is the front line in providing essential health services in the community. However, several complaints were still found in the health services provided, which also decreased public access to the Puskesmas. This study aims to determine the quality of outpatient health services at the UPT Puskesmas Ciputat Timur in 2019. This research is an evaluation study using a descriptive-analytical survey method with a quantitative approach with a cross-sectional study design. The sample determination was based on the Probability Proportionate to Size sampling technique with a total sample of 341 samples according to the sample table from Krejcie and Morgan. Data were collected using a questionnaire with two methods of measuring service quality, namely Servqual and Community Satisfaction Index, and using univariate data analysis. The results of this study stated that outpatient satisfaction at the UPT Puskesmas Ciputat Timur was 2.16 (satisfactory) based on the servqual concept and 76.47 (good) based on the concept of community satisfaction index. This study concludes that the quality of outpatient health services at the UPT Puskesmas Ciputat Timur is good, although several items still need to be improved. Suggestions are needed to make information boards for patient registration requirements, increase discipline in-service time, make persuasive stickers or posters, add RM distribution officers, publish IKM results annually through the website and add waiting room seats for patients and their families.
\end{abstract}

Keyword: Patient satisfaction, Servqual, Community Satisfaction Index 


\section{INTRODUCTION}

Health service is one of the factors that influence the status of public health status. (1) Health services are included in one of the scopes of public services. (2) In its implementation, public services are deemed not fulfilling the expectations of the community, if this is not fixed it will cause a sense of distrust from the community. other than that quality health services can increase patient loyalty to re-choose health services in the future. (3)

Some of the problems encountered in public health services include the lack of speed of services provided by officers, incomplete facilities and infrastructure, an uncomfortable and less conducive environment. (4) Other research states that complaints that are felt by the community include poorly maintained room cleanliness and a very minimal number of paramedics (5) and $41.5 \%$ of the lowest service quality was found in the outpatient unit. (6) Various health problems become a new challenge for health service providers to meet the needs of the community.

In overcoming this problem, the Minister of State Apparatus Empowerment has made general guidelines to determine the index of public satisfaction in public services. (7)regarding Guidelines for Preparing Community Satisfaction Surveys for Public Service Management Units. However, in the implementation of health services, they have different characteristics from other public services, because to measure the quality of their services, they must adjust to the characteristics of health services. One of its characteristics is asymmetry of information, which is a state of imbalance between the knowledge held by health workers and patients. Due to the lack of information owned by the patient (customer ignorance), the patient will leave it completely to the health worker to take action.

UPT Puskesmas Ciputat Timur is one of the administrators of public health services. Based on the results of preliminary studies on patients, some complaints were found, including the service time at the registration counter and the patient queuing time for doctor calls, and the provision of trash cans were deemed insufficient and some officers were less friendly in serving patients. Based on several research results, it was found that there was a relationship between service quality and patient satisfaction at Tigo Baleh Bukit Tinggi Health Center. (8) This is supported by the results of research which states that the quality of health services at Kelayan Health Center in Banjarmasin City with the level of patient satisfaction has a relationship. (9)

One of the SDGs targets in achieving UHC is increasing access to quality essential health services. Puskesmas are required to be able to provide quality essential health services, but there are still several complaints about the health services provided. Quality of service is 
important in influencing patient satisfaction so that patients continue to want to access health services at the Puskesmas. Seeing this, this research is needed to see the quality of health services at the Puskesmas.

\section{METHODS}

This research is an evaluation study using a descriptive-analytic survey method with a quantitative approach with a cross-sectional study design. The research was conducted at UPT Puskesmas Ciputat Timur 2019 from April 1 to 8 2019, the number population-based on patient visit data in February 2019 amounted to 3,088 patients and a sample size of 341 patients, the determination of the sample in this study used the Probability Proportionate to Size Sampling technique, with the distribution of 158 general polyclinic patients, 104 elderly patients, $46 \mathrm{MCH}$ patients, 28 dental patients, and 5 pulmonary patients. Data were collected using a questionnaire that has been tested for validity and reliability with a Cronbach alpha value of 0.96 . The quality of health services is measured using 2 methods, namely Servqual and Satisfaction Index. Data were analyzed descriptively.

\section{RESULTS AND DISCUSSIONS}

Based on the results of filling out the questionnaire, 341 respondents have given their assessment of the quality of health services by answering some information.

\section{Quality of health services according to Servqual}

Based on the results of research from 5 dimensions of service quality, 3 dimensions are considered satisfactory, namely responsiveness (1.24), empathy (1.09), and tangibles (1.00). Furthermore, 2 dimensions that were considered unsatisfactory were reliability $(-0.73)$ and assurance (-0.44). Overall, the overall service dimension gap score is (2.16), which means that the quality of health services in the outpatient unit of the UPT Puskesmas Ciputat Timur is considered satisfactory.

Table 1. Quality of Health Services According to Servqual

\begin{tabular}{lcccl}
\hline \multirow{2}{*}{ Service Dimensions } & \multicolumn{2}{c}{ Mean } & \multirow{2}{*}{ Gap } & \multirow{2}{*}{ Information } \\
\cline { 2 - 3 } & Hope & Reality & & \\
\hline Tangibles & 19.30 & 20.30 & 1.00 & Satisfied \\
\hline Reliability & 16.77 & 16.04 & -0.73 & Not satisfied \\
\hline Responsiveness & 9.42 & 10.66 & 1.24 & Satisfied \\
\hline Assurance & 13.75 & 13.31 & -0.44 & Not satisfied \\
\hline Empathy & 12.86 & 13.95 & 1.09 & Satisfied \\
\hline Total & $\mathbf{1 2 . 8 6}$ & $\mathbf{1 3 . 9 5}$ & $\mathbf{2 . 1 6}$ & Satisfied \\
\hline
\end{tabular}




\section{Patient satisfaction level based on Importance Performance Analysis (IPA)}

Based on the distribution diagram of the attributes studied in 4 quadrants, with the following results. Quadrant A, namely modern health equipment (1), health centers tell patients when services are ready to be provided (12), services are provided responsively (13), officers have a polite attitude (17), officers do not differentiate between patients (19), doctors provide individual attention to the patient (20). Quadrant B, namely a clean and well-maintained bathroom (2), an adequate waiting room (3), communication between officers and patients is running well (21), and doctors explain the patient's illness (22). Quadrant C, namely adequate parking space (4), clean, tidy and private care rooms (5), officers have a neat appearance (6), health centers provide services as promised (7), reliable officers (8) officers have extensive knowledge (18), officers show a willingness to help patients (14), officers make patients feel safe and comfortable (16). Quadrant D, namely officers serving immediately (9), doctors present late (10), doctors diagnosing carefully and accurately (11) and officers growing confidence in patients (15).

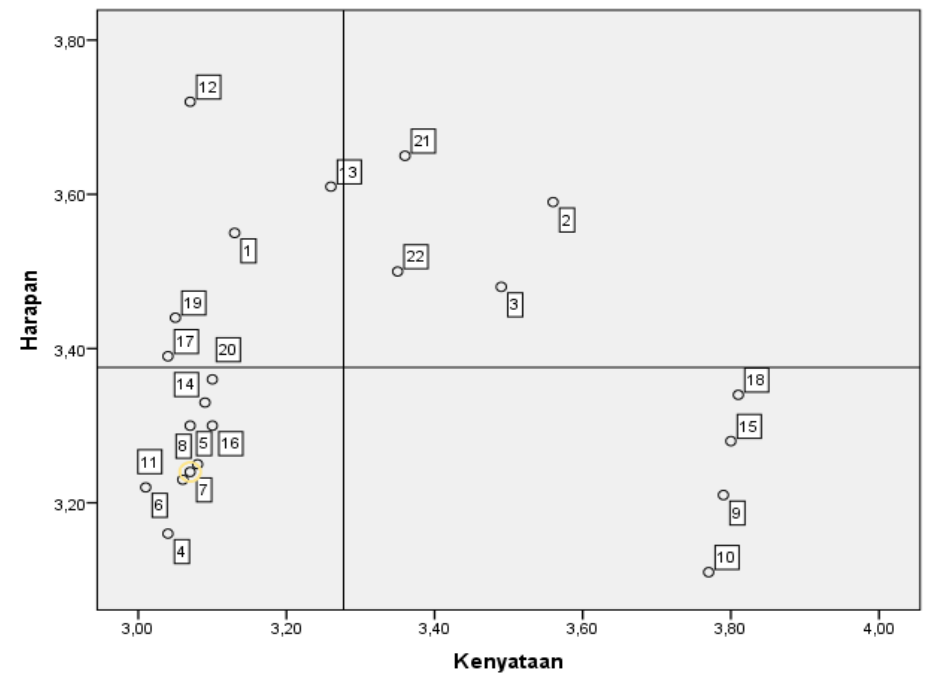

Chart 1. Satisfaction Level based on Importance Performance Analysis (IPA)

\section{Quality of Health Services Based on the Concept of Community Satisfaction Index}

Based on table 5.12, it is known that from the 9 elements of the community satisfaction index, 6 elements have a good IKM value according to the average value (NRR), namely costs/rates (3.66), requirements (3.17), behavior of officers and systems, mechanisms and 
procedures $(3,14)$, product specifications for the type of service and competence of officers $(3,10)$. Meanwhile, 3 elements that have a bad IKM value are complaint handling, suggestions and input (2.92), facilities and infrastructure (2.89), and completion time (2.74). In total, the weighted average value of the community satisfaction index is (3.063), after converting the IKM value multiplied by the basic value, namely 25 , it gets a value of (76.575) meaning the quality of service quality of outpatient units at UPT Puskesmas Ciputat Timur gets a B (Good).

Table 2 Quality of Health Services Based on the IKM Concept

\begin{tabular}{lccc}
\hline \multicolumn{1}{c}{ Elements of Service } & NRR & IKM Value & $\begin{array}{c}\text { Score } \\
\text { Weighted }\end{array}$ \\
\hline Requirements & 3.17 & Good & 0.348 \\
\hline System Mechanisms, and Procedures & 3.14 & Good & 0.345 \\
\hline Completion Time & 2.74 & Not good & 0.301 \\
\hline Fees / Rates & 3.66 & Good & 0.402 \\
\hline Product Specifications Type of Service & 3.10 & Good & 0.341 \\
\hline Officer Competence & 3.10 & Good & 0.341 \\
\hline Officer Behavior & 3.14 & Good & 0.345 \\
\hline $\begin{array}{l}\text { Handling of Complaints, Suggestions, } \\
\text { and Inputs }\end{array}$ & 2.92 & Not good & 0.322 \\
\hline Facilities and infrastructure & & \\
\hline IKM Weighted NRR & 2.89 & Not good & 0.318 \\
\hline
\end{tabular}

Based on the tangibles dimension it is satisfactory (1.00) but the service attributes in the waiting room are considered inadequate $(-0.01)$ this is in line with several previous studies which also show that the quality of the service waiting room is not satisfactory(10) (11). Based on the results of observations, this is because the number of outpatients continues to increase and patients who seek treatment often not only come and wait alone but are accompanied by relatives or family so that the seats provided for waiting are inadequate in terms of quantity, therefore many patients have to stand while waiting for the doctor's examination and make the patient feel uncomfortable.

Based on the reliability dimension, it is considered unsatisfactory (-0.73). Several service attributes that were considered unsatisfactory were the officers serving immediately ($0.58)$ and the doctor was present on time to examine the patient $(-0.66)$, this is in line with several previous studies which stated that the presence of a doctor to check still had value. The low one. (12) This may also be because the condition of a person who is sick will affect their emotional factors so that they tend to be sensitive and have high expectations to be served quickly, accurately, safely, and attentively. (13). Based on the results of observations to serve the patient, the doctor must wait for the patient's medical record to be delivered to the service clinic. While the medical record officer will deliver medical record files if there are more than 5 
files, this is by previous research, namely the cause of the long waiting time for patients due to the often late distribution process of medical records. (14). Based on the results of observations, the number of persons in charge of medical records is only one person with the task of finding medical records, preparing medical records according to the service clinic, and also distributing them. Besides, no SOP regulates the implementation of these medical records.

Based on the responsiveness dimension, it is satisfactory (1.24), this is by (13)which states that the level of patient satisfaction for the responsiveness dimension is quite high, namely $73.7 \%$. Based on the observations of the UPT Puskesmas Ciputat Timur officers, they are always informative, responsive, and willing to help patients and its implementation refers to outpatient SOPs and always upholds the puskesmas motto.

Based on the assurance dimension, it is considered unsatisfactory (-0.44), the service attributes that are considered unsatisfactory are found in the officers to grow confidence in the patient $(-0.52)$ and the officers have about patient knowledge $(-0.48)$. Based on the results of observations, this was due to the lack of discipline of the officers by previous research where the level of discipline of officers gave $74.14 \%$ of patient satisfaction at the puskesmas. (15)

Based on the empathy dimension, it is satisfactory (1.09). This is by previous research which states that the empathy dimension gets a value of $80.88 \%$ meaning that the patient is satisfied with the empathy dimension. (16) Based on these observations, it is supported by puskesmas officers who carry out their duties by always referring to the applicable SOP so that there is no discrimination of patients. (10)

\section{Analysis of patient satisfaction levels based on Importance Performance Analysis (IPA)}

Quadrant A (high importance, low performance) shows the location of the strength of the UPT Puskesmas Ciputat Timur in meeting patient needs. So that the strategy for handling service attributes in quadrant A needs to be prioritized because the existence of these service attributes is considered important. So that what needs to be done is UPT Puskesmas Ciputat Timur, it is better to procure more modern medical devices and improve the attitude of health workers and doctors in serving patients such as always being informative, polite, not discriminating against patients.

Quadrant B (high importance, high performance) shows the service attributes needed and considered very important by the patient. So that the thing that needs to be done is UPT Puskesmas Ciputat Timur, it is better to maintain a clean and well-maintained bathroom, adequate waiting room, as well as good communication between officers and doctors to patients. 
Quadrant C (low importance, low performance) shows the weaknesses of the UPT Puskesmas Ciputat Timur because it is included in low priority and is considered less important for the needs of outpatient units so that the strategy for handling service attributes in quadrant $\mathrm{C}$ is to improve the performance of these health service attributes after improving service attributes which are contained in quadrant A. So that things that need to be done, should make the parking lot more comfortable, pay more attention to the cleanliness and tidiness of the treatment room and also maintain patient privacy during treatment, increase the tidiness of the appearance of officers and increase the competence of officers by conducting training routine.

Quadrant D (low importance, high performance) is considered less important by outpatients, while in practice it is good so that it seems excessive but considered satisfactory so that the strategy for handling service attributes in quadrant $\mathrm{D}$ is simply maintaining it because it can create patient loyalty. So that the thing that needs to be done should be to maintain the attitude of the officers who are alert and have the confidence that the patients and doctors are present on time and diagnose patients carefully and accurately.

\section{Quality of Health Services Based on the Concept of Community Satisfaction Index}

The outpatient registration requirements are good $(3,17)$, this is by $(4)$ which states that the patient has assessed both the elements of the requirements, by previous research which states that the suitability of both technical and administrative requirements required by the patient is $\operatorname{good}(17)$ therefore it is easy for the patient to complete these requirements. (18) Based on the results of observations, this is because there is a notification on the glass of the registration counter which contains what requirements must be prepared, such as bringing medical cards and KTP / KK for free patients as well as medical cards and BPJS / KIS / Askes / Jamkesmas participant cards for patients. who use health insurance.

The ease of systems, mechanisms, and procedures for outpatient units is good $(3,14)$. This is by previous research which states that the ease of systems, mechanisms, and procedures starting from the registration section until the service is completed is felt by both new and old patients. (19) And there is a relationship between service procedures and patient satisfaction(20) Therefore, the UPT Puskesmas Ciputat Timur has explained how the flow of outpatient services is in an information board which is a very strategic place to be seen by visiting patients.

The time speed of completion of the outpatient unit is not good (2.74). This is by previous research that the speed of time and the accuracy of the service schedule is considered poor. (21) (22) This is because the UPT Puskesmas Ciputat Timur does not yet have an SOP 
that determines the time limit for each outpatient service and is also related to the discipline of officers starting the service time. (23)

The cost/tariff for outpatient units is good (3.66), this is by previous research which states that the cost of services at the Puskesmas is reasonable because BPJS participants are free of medical costs. (24)This is because the majority of the UPT Puskesmas Ciputat Timur is free. After all, the patient uses a South Tangerang KTP / KK and also uses a health insurance card such as BPJS Kesehatan. So even though the patient has to pay only 35,000 for the cost of examining/consulting a general practitioner at the polyclinic. (25)

The suitability of the product specification for the type of outpatient service unit is good (3.10), this is by previous research which states that the product specification for the type of service received is by the patient's expectations and applicable regulations. (26) This is because the UPT Puskesmas Ciputat Timur has carried out its duties and obligations according to the applicable SOP to minimize complaints from patients.

The competency of the outpatient unit is good $(3,10)$. This is because the UPT Puskesmas Ciputat Timur regularly holds meetings and also coordinates with the South Tangerang Health Office so that the competence of officers at the UPT Puskesmas Ciputat Timur is always updated regarding the latest regulations and also increases their knowledge regarding how to provide good and correct services. According to previous research, it was stated that the element of officers' competence affected the use and management of other resources such as drugs and medical devices. (5)

The behavior of the outpatient unit executor is good (3.14), this is by previous research which states that the element of the implementer's behavior is 3.16. (4)This is because based on the observations of the UPT Puskesmas Ciputat Timur officers always apply 5S, namely Smile, Greetings, Greetings, Polite and Courteous in serving patients. One of the implementations of excellent service in the health sector is that health workers must have a good attitude, politeness, be friendly and strive to provide the best possible service. (27)

The handling of complaints, suggestions, and input from the outpatient unit is not good (2.92). This is because the UPT Puskesmas Ciputat Timur has a suggestion box that is not strategic enough for the patient to see. According to previous research, it was stated that there were still many patients who submitted their complaints through the mass media which could indirectly give a negative image to the institution. (28) the UPT Puskemas Ciputat Timur has provided a suggestion box and there is also a follow-up from the suggestion box, but the results are not published to patients. 
Outpatient facilities and infrastructure are not good (2.89), this is by previous research which states that the elements of facilities and infrastructure are still deemed inadequate. (29) Based on the results of observations, the provision of facilities and infrastructure is good, but this is not supported by their maintenance.

\section{Difference Between Health Service Quality Results Based on Servqual Concept and Community Satisfaction Index}

There is no difference in the quality of outpatient health services at the UPT Puskesmas Ciputat Timur which is considered good. Based on the Servqual concept, the quality of outpatient health services received an average score of 2.16 (satisfactory), and based on the concept of the Community Satisfaction Index, the quality of outpatient health services at UPT Puskesmas Ciputat Timur has an average value of 76.475 (good ).

There are several ways to determine the reliability of an instrument, one of which is the method used in this study is the parallel method (equivalent-form reliability), which is to use different instruments to measure the same variable using the same respondent and at the same time, if the results of the instrument are reliable. so even if it is used repeatedly with the same subject, the results will be the same or consistent. (30) Based on research that measures the quality of health services at the South Tangerang General Hospital using the Servqual concept, the results (93.80) are satisfactory(31) then using the concept of Community Satisfaction Index get the same result, namely (72.42) good value. (5) This is reinforced by other research that measures the quality of health services at the UPT Puskesmas Ciputat Timur using the Servqual concept with the results of the five elements of good service. (32)then based on the Community Satisfaction Index data at the UPT Puskesmas Ciputat Timur 2018 got the same results, namely (77.65) good scores. Based on this explanation, it can strengthen the findings from the results of this study where if measured using two different instruments at the same health service place, the results are also the same.

Based on the results of field observations, UPT Puskesmas Ciputat Timur has been supported by good service facilities such as modern health equipment to strengthen the accuracy of doctors in diagnosing patient diseases, clean and well-maintained bathrooms, and adequate parking for patients and their families. In addition, the human resources owned by the UPT Puskesmas Ciputat Timur are competent according to their respective fields, behave politely and are friendly, and look neat when serving patients and based on costs or rates are also very satisfying because the UPT Puskesmas Ciputat Timur exempts fees for registration using KTP / 
KK. South Tangerang and health insurance patients. As for patients other than that, only pay 35,000 for the doctor's consultation fee.

\section{CONCLUSION AND SUGGESTIONS}

Based on the Servqual concept, the quality of health services is considered satisfactory (2.16) and based on the concept of Community Satisfaction Index service quality B with good performance (76.47). So that overall, the quality of outpatient health services at the UPT Puskesmas Ciputat Timur is good.

However, several indicator items show a low value based on the Servqual concept, namely Reliability and Assurance. Meanwhile, based on the IKM concept of Settlement Time, Complaint Handling, Suggestions and Inputs, and Facilities and Infrastructure.

Suggestions for the UPT Puskesmas Ciputat Timur, especially the registration counter section, should make an information board for patient registration requirements that is attractive and clear to be displayed in strategic places so that no more patients forget to bring these requirements, for all outpatients, it is better to improve their discipline in medical service time and administration so that patients who can be served quickly and appropriately can be fulfilled, for the health promotion section, it is preferable to make persuasive stickers or posters that contain invitations to patients and their families to keep each other clean as well as care for facilities and infrastructure, for the medical record section to add a special officer for the distribution, for the quality team, the results of the IKM are published annually through the UPT Puskesmas Ciputat Timur website, and for the administration department, it is better if the waiting room seats are added for patients and their families so that patients and their families feel more comfortable.

\section{REFERENCES}

1. Blum H. Planning for Health: Generics for The Eighties. Human Sciences Press. 1981.

2. RI Law No. 25. About Public Services. 2009.

3. Nofiana H. Relationship Quality of Registration Service with Outpatient Satisfaction at PKU Muhammadiyah Karanganyar Hospital. 2012; V (1): 90-106.

4. Eka S. Community Satisfaction Index Against Health Services in Serang City Health Center. 2016.

5. Al-Aufa B. Description of Quality and Performance Based on the Community Satisfaction Index at the Emergency Room (IGD) General Hospital of South Tangerang City. 2013; Thesis (Public Health Study Program, Faculty of Health Sciences, Syarif Hidayatullah 
State Islamic University Jakarta).

6. Sarah, Imelda. and Ezzah N. Analysis of Quality Level of Inpatient Services in Efforts to Increase Patient Satisfaction at Adam Malik General Hospital Medan (Comparative Study Between General Patients and BPJS Patients). No Title. J Ilm AMIK Labuhan Batu. 2015; 03.

7. Permenpan Number 14. Guidelines for Preparing Community Satisfaction Surveys for Public Service Provider Units. 2017;

8. Andriani A-. Relationship between Health Service Quality and Patient Satisfaction in Public Polyclinic Room at Puskesmas Bukittinggi. J Endur. 2017; 2 (1): 45.

9. Rizal A, Riza Y. The relationship between the quality of health services and the level of patient satisfaction at Bp.Gigi Puskesmas Kelayan Dalam, Banjarmasin. An Nadaa. 2014; 1 (1): 26-31.

10. Ginting T. Analysis of the quality of outpatient services at the Puskesmas Berastagi, Karo Regency. J thesis) Master Program and Public Policy Univ Indones Jakarta http // lib UI ac id (Accessed 3 October 2016). 2012;

11. Septia D. Satisfaction with BPJS Health Service Quality (Case Study at Abdul Moeloek Hospital, Lampung Province). 2017;

12. Deharja A et al. Satisfaction Analysis of Outpatient Bpjs Patients with Servqual, CSI and IPA Methods in Dr. M. Suherman. 2017; 5 (2): 106-15.

13. Sulistiyowati B. Analysis of Service Quality (SERVQUAL) Dimensions of Nursing Care in General Care Rooms I and II at RS. Cisalak Medika Center in 2010. 2011;

14. Bustami. Health Service Quality Assurance and Acceptability. (PA Rina astikawati E)., Editor. Padang; 2014.

15. Nurba. Analysis of Public Service Satisfaction Levels at Puskesmas Loa Janan. Exist. 2012; 8. No.2(2):2298-308.

16. Eninurkhayatun B, Suryoputro A, Fatmasari EY. Analysis of Patient Satisfaction Levels on Outpatient Service Quality at Puskesmas Duren and Puskesmas Bergas Semarang Regency in 2017. J Public Health. 2017; 5: 33-42.

17. Hamka. Analysis of Community Satisfaction Index with ServiceHealth at the Puskesmas. Glob Heal Sci. 1 (2): 6.

18. Nawawi M. Community Satisfaction Survey for Health Services at RSUD DR. Soedarsono, West Kalimantan Province. J Government Polit. 2016; 9 (1): 13-23.

19. Qodir A. Analysis of Community Satisfaction Index at Puskesmas Sambeng Lamongan. 
2018;

20. Setyobudi E. The Relationship between Administration Service Flow and Patient and Family Satisfaction in the Implementation of JKN at RSD Balung Jember. 2015;

21. Yulian R. Optimization of Puskesmas Services in Improving the Quality of Public Health Services in Kubu Raya District, West Kalimantan Province. J Faculty of Economics and Business. 2017; 13 (2): 850-67.

22. Romliyadi. Oxyandi M. BPJS Health Patient Satisfaction Index in Outpatient Installation 2018. J Ilm Health Sci. 2018; 8: 1-13.

23. Yusnita DW. An overview of the Community Satisfaction Index at Tegal Angus Health Center in the Era of National Health Insurance. Glob Med Heal Commun. 2017; 5 (No. 1).

24. Rosalinda Y, Rochmah S. Level of Community Satisfaction at Jamkesmas Services (Study at Janti Health Center, Malang City). 2005; 2 (2): 294-9.

25. South Tangerang City Regional Regulation No. 9 of 2014 concerning Regional Levies. 2014;

26. Harahap HK. Analysis of Inpatient Satisfaction Index at Gunung Tua District General Hospital (RSUD)North Padang Lawas 2017. 2018.

27. wahdania. Saleh SF. Patient Satisfaction Index Against Public Hospital Services (RSUD) Polewali Mandar Regency. Public Administration Journal; 2015.

28. Frederik Mote. Analysis of Community Satisfaction Index (IKM) Against Public Services at Puskesmas Ngesrep Semarang. 2008.

29. Ristiani IY. The Influence of Infrastructure and Service Quality on Patient Satisfaction (Study of Outpatients of the IPDN Jatinegoro Polyclinic Unit). J Coopetition. 2017; 8 (2): $155-66$.

30. Danim S and D. Midwifery Research Methods: Procedures, Policies, and Ethics. Jakarta: EGC Medical Book; 2003.

31. Pangestu AY. Description of Patient Satisfaction in Outpatient Services at RSU Kota Tangerang Selatan. 2013; 2 (SGEM2016 Conference Proceedings, ISBN 978-619-7105-162 / ISSN 1314-2704): 1-39.

32. Halimatusa'diah. The Relationship between Patients' Perceptions of Service Quality and Interest in Reuse of Public Outpatient Care at Puskesmas Ciputat Timur. 2015. 